\title{
Moroccan Monofloral Bee Pollen: Botanical Origin, Physicochemical Characterization, and Antioxidant Activities
}

\author{
El Ghouizi Asmae (D), El Menyiy Nawal (D), Meryem Bakour (iD, and Badiaa Lyoussi \\ Laboratory of Natural Substances, Pharmacology, Environment, Modeling, Health, and Quality of Life (SNAMOPEQ), \\ Department of Biology, Faculty of Sciences Dhar Mehraz, Sidi Mohamed Ben Abdellah University, Fez 30000, Morocco
}

Correspondence should be addressed to Badiaa Lyoussi; lyoussi@gmail.com

Received 30 August 2020; Revised 31 October 2020; Accepted 24 December 2020; Published 7 January 2021

Academic Editor: Vera Lavelli

Copyright (C) $2021 \mathrm{El}$ Ghouizi Asmae et al. This is an open access article distributed under the Creative Commons Attribution License, which permits unrestricted use, distribution, and reproduction in any medium, provided the original work is properly cited.

\begin{abstract}
In this study, eight monofloral bee pollen samples were collected from different apiaries in Morocco. Botanical origins of the bee pollen samples were determined by scanning electron microscopy (SEM), and the physicochemical parameters ( $\mathrm{pH}$, moisture, ash, and the mineral contents) were determined. Total phenolic, flavones/flavonols contents were evaluated, and the antioxidant potential was assessed using total antioxidant capacity, DPPH, ABTS, and reducing power assays. Data showed that $\mathrm{pH}$, moisture, and ash content values ranged between $4.19 \pm 0.17$ and $4.82 \pm 0.36,10.7 \pm 0.04 \%$ and $26.8 \pm 0.01 \%$, and $1.81 \pm 0.10 \%$ and $4.22 \pm 0.08 \%$, respectively. Potassium and magnesium were the most abundant minerals in bee pollen samples; heavy metals were not detected except for two samples (P5 and P6) where a very small amount of lead was found. The protein content in these samples varied between $19.86 \pm 0.36 \mathrm{mg} / 100 \mathrm{~g}$ and $30.32 \pm 0.12 \mathrm{mg} / 100 \mathrm{~g}$ of bee pollen. The phenolic content, flavones/flavonols content, and total antioxidant capacity were $21.87 \pm 1.80 \mathrm{mgEAA} / \mathrm{g}, 2.37 \pm 0.16 \mathrm{mgEAA} / \mathrm{g}$, and $6.23 \pm 0.21 \mathrm{mgEAA} / \mathrm{g}$, respectively. High scavenging activity of DPPH and ABTS radicals was found in P2 with the lower $\mathrm{IC}_{50}$ of $0.245 \pm 0.009 \mathrm{mg} / \mathrm{ml}$ and $0.19 \pm 0.005 \mathrm{mg} / \mathrm{ml}$, respectively. The lower $\mathrm{EC}_{50}$ was $0.133 \pm 0.036 \mathrm{mg} / \mathrm{ml}$ found in $\mathrm{P} 1 \mathrm{for}$ the reducing power test. The current study is considered to be the first step to the standardization of Moroccan bee pollen.
\end{abstract}

\section{Introduction}

Bee pollen is considered as the final result of agglutination of pollen grains from flowers collected by worker honey bees, held together with nectar and/or honey and glandular secretions and collected at the entrance of the hive [1].

Bee pollen is an important bee product gaining attention as a functional food. It is renowned for its high content of biocompounds with health-promoting effects on human physical and mental well being, which make it the last trend of diet supplementation $[2,3]$. It is commonly named the only perfectly complete food" because it is the most energetic, the richest hive product in nutrients, and contains the most active substances such as carbohydrate, crude fiber, and protein. It contains also all the essential amino acids, lipids, vitamins, and minerals that the human body needs. Additionally, bee pollen presents an excellent source of antioxidant compounds such as polyphenols, flavonoids, carotenoids, and vitamins $\mathrm{A}, \mathrm{C}$, and $\mathrm{E}$, conferring to this bee product a great antioxidant potential $[4,5]$.

Thanks to the high load of natural antioxidants, bee pollen is the richest valued food in micronutrients. The literary data point out that bee pollen is responsible for a long list of pharmacological effects such as detoxifying action, hypolipidemic, hypoglycemic, anti-inflammatory, and antibacterial activities $[5,6]$.

Morocco is a Mediterranean country ranked second in the world in terms of plants and floral biodiversity with almost 7000 plants [7]. Agricultural authorities focused on honey production; however, they neglected the other hive products such as royal jelly, propolis, and bee pollen. These facts turn into a lack of scientific studies concerning the national bee pollen. This emanates the aim of the current study: the characterization for the first time of Moroccan bee 
pollen, according to its floral origin, physicochemical properties, bioactive molecules, and their antioxidant activity.

\section{Materials and Methods}

2.1. Bee Pollen Samples. Eight samples of bee pollen were collected by professional beekeepers from different regions of Morocco and were kept in the refrigerator until use (Table 1). All hives were free from pesticide use and any pathogens.

2.2. Scanning Electron Microscopy. Scanning electron microscopy (SEM) observation was used for palynological analysis following the protocol described by Almeida et al. [8] Briefly, $2 \mathrm{~g}$ of the bee pollen sample was used for analysis, the pollen loads were grouped up into subsamples according to their coloring, and each subsample was placed onto the SEM stub and layered with carbon conductive adhesive tape. The percentage of each pollen grain was determined from a total of 350 pollen grains. According to Louveaux et al., the following terms are used to classify the percentages of pollen grains obtained: "predominant pollen grains" ( $>45 \%$ of total); "secondary pollen grains" (16-45\% of total); "important minor pollen" (3-15\% of total), and "minor pollen" ( $<3 \%$ of total) [9].

The observations are carried out at the SEM of the regional university interface center, of the University Sidi Mohammed Ben Abdellah, Fez.

2.3. Bee Pollen Extracts. The extraction was carried out by maceration of one gram of bee pollen in $10 \mathrm{~mL}$ of $70 \%$ ethanol for 1 week under agitation, and then, the solution was sonicated for 30 minutes by an ultrasonic vibrator and then filtered through Whatman No. 1 filter paper. The extract obtained was stored in $-20^{\circ} \mathrm{C}$ until analysis [10].

2.4. $\mathrm{pH}$. The $\mathrm{pH}$ value was determined with a $\mathrm{pH}$ meter from a solution of $10 \mathrm{~g}$ of bee pollen samples dissolved in $40 \mathrm{~mL}$ of distilled water. Tests were conducted three times, and the results were expressed as the mean average \pm SD [11]

2.5. Moisture. Three $\mathrm{g}$ of sample was weighed and heated at $65^{\circ} \mathrm{C}$ for $24 \mathrm{~h}$. Moisture content was obtained by the difference between the initial and final weight, and the results were expressed as the mean average \pm SD [12].

2.6. Ash. Ash content was determined using the gravimetric method after incineration in an oven at $550^{\circ} \mathrm{C}$, and until constant weight, the residue was weighed in an analytical balance. The determination of ash content was carried out in triplicate, and the mean was expressed as percentage \pm SD [11].

2.7. Protein. The protein content was measured according to the method described by Lowry et al. [13]. The standard curve was prepared by the Bovine Serum Albumin (BSA), and the concentration varied from 0.3 to $300 \mu \mathrm{g} / \mathrm{ml}$. The absorbance was measured in 750 against the distilled water as the blank, and the equation of the calibration curve of BSA was as follows:

$y=3.6702 x+0.0927, R^{2}=0.9825$. The experiment was performed in triplicates, and the results were expressed as mean \pm SD g/100 $\mathrm{g}$ of bee pollen.

2.8. Mineral Content. Minerals were determined using the ash obtained after incineration and adding $5 \mathrm{~mL}$ of nitric acid $0.1 \mathrm{M}$. The mixture was heated to complete dryness. $10 \mathrm{~mL}$ of the same acid was added, and the mixture was made up to $25 \mathrm{~mL}$ with distilled water. The inductively coupled plasma mass spectrometry (ICP-MS) was used for the determination of 11 elements ( $\mathrm{Ca}, \mathrm{Na}, \mathrm{Fe}, \mathrm{K}, \mathrm{Mg}, \mathrm{Cu}, \mathrm{Zn}$, $\mathrm{Al}, \mathrm{Ni}, \mathrm{Cd}$, and $\mathrm{Pb}$ ). The results were calculated as $\mathrm{mg}$ of each element per $\mathrm{Kg}$ of bee pollen [12].

2.9. Total Phenolic Content. Total phenolic content in the bee pollen samples was determined by the Folin-Ciocalteu colorimetric method according to singleton et al. [14]. $50 \mu \mathrm{L}$ of ethanolic extract of bee pollen was mixed with $250 \mu \mathrm{L}$ of the Folin-Ciocalteu reagent $(0.2 \mathrm{~N})$ and $200 \mu \mathrm{L}$ of $(75 \mathrm{~g} / \mathrm{L})$ $\mathrm{Na}_{2} \mathrm{CO}_{3}$. The absorbance was measured at $760 \mathrm{~nm}$ after $2 \mathrm{~h}$ of incubation.

The experiment was performed in triplicates, and the results were expressed as mean $\pm \mathrm{SD}$ mg equivalent of gallic $\mathrm{acid} / \mathrm{g}$ of bee pollen.

2.10. Flavones and Flavonols Content. Flavones and flavonols content was quantified according to the method described by Miguel et al. [15]. Briefly, to $50 \mu \mathrm{l}$ of the sample or standard, we added $200 \mu \mathrm{l}$ of $\mathrm{AlCl}_{3}$ (2\%). After 1 hour, the absorbance was measured at $420 \mathrm{~nm}$. Quercetin was used as standard, and flavones/flavonols content was expressed as mg quercetin equivalents per $\mathrm{g}$ of bee pollen ( $\mathrm{mg} \mathrm{QE} / \mathrm{g}$ ). Tests were performed in triplicate, and the results are given as mean \pm SD.

2.11. Total Antioxidant Capacity. The total antioxidant capacity (TAC) was determined according to the ammonium molybdate colorimetric method of Prieto et al. [16]. Briefly, $50 \mu \mathrm{l}$ of ethanolic extract of bee pollen was added to $1 \mathrm{ml}$ of reagent solution $(0.6 \mathrm{M}$ sulfuric acid, $28 \mathrm{mM}$ sodium phosphate, and $4 \mathrm{mM}$ ammonium molybdate). The mixture was capped and incubated in a thermal block at $95^{\circ} \mathrm{C}$ for $90 \mathrm{~min}$. The absorbance of the reaction mixture was measured at $700 \mathrm{~nm}$ against a blank. Ascorbic acid was employed as the standard calibration, and the results were expressed as milligrams of ascorbic acid equivalent per gram of bee pollen.

2.12. Free-Radical Scavenging Activity (DPPH). The radical scavenging activity of ethanolic extract of bee pollen against 2, 2-diphenyl-1-picrylhydrazyl (DPPH) free radical was 
TABLE 1: Geographical location, bee breed, and harvesting period of bee pollen samples.

\begin{tabular}{|c|c|c|c|c|c|c|c|}
\hline Sample & Bee breed & Location & Latitude & Longitude & $\begin{array}{l}\text { Altitude } \\
(\mathrm{m})\end{array}$ & $\begin{array}{l}\text { Pluviometry and } \\
\text { temperature }\end{array}$ & $\begin{array}{c}\text { Harvest } \\
\text { year }\end{array}$ \\
\hline P1 & $\begin{array}{c}\text { Apis mellifera } \\
\text { intermissa }\end{array}$ & LARACHE & $35.1744^{\circ} \mathrm{N}$ & $6.1474^{\circ} \mathrm{W}$ & 40 & $\begin{array}{c}1 \text { to } 141 \mathrm{~mm} \\
6 \text { to } 30.6^{\circ} \mathrm{C}\end{array}$ & 2015 \\
\hline $\mathrm{P} 2$ & $\begin{array}{c}\text { Apis mellifera } \\
\text { intermissa }\end{array}$ & KHENICHAT & $34^{\circ} 25^{\prime} 47^{\prime \prime} \mathrm{N}$ & $5^{\circ} 39^{\prime} 36^{\prime \prime} \mathrm{W}$ & 32 & $\begin{array}{l}2 \text { to } 77.3 \mathrm{~mm} \\
12.4 \text { to } 25.7^{\circ} \mathrm{C} \\
\end{array}$ & 2016 \\
\hline P3 & $\begin{array}{c}\text { Apis mellifera } \\
\text { intermissa }\end{array}$ & HAD KOURT & $34^{\circ} 62^{\prime} \mathrm{N}$ & $5^{\circ} 74^{\prime} \mathrm{W}$ & 103 & $\begin{array}{c}2 \text { to } 70 \mathrm{~mm} \\
12 \text { to } 34^{\circ} \mathrm{C}\end{array}$ & 2014 \\
\hline $\mathrm{P} 4$ & $\begin{array}{c}\text { Apis mellifera } \\
\text { intermissa }\end{array}$ & KENITRA & $34.2541^{\circ} \mathrm{N}$ & $6.5890^{\circ} \mathrm{W}$ & 23 & $\begin{array}{l}0 \text { to } 114 \mathrm{~mm} \\
12.2 \text { to } 24.8^{\circ} \mathrm{C}\end{array}$ & 2017 \\
\hline P5 & $\begin{array}{c}\text { Apis mellifera } \\
\text { intermissa }\end{array}$ & FEZ & $34.0181^{\circ} \mathrm{N}$ & $5.0078^{\circ} \mathrm{W}$ & 410 & $\begin{array}{c}1 \text { to } 78 \mathrm{~mm} \\
9.9 \text { to } 27.2^{\circ} \mathrm{C}\end{array}$ & 2016 \\
\hline P6 & $\begin{array}{c}\text { Apis mellifera } \\
\text { intermissa }\end{array}$ & SEFROU & $33.8305^{\circ} \mathrm{N}$ & $4.8353^{\circ} \mathrm{W}$ & 850 & $\begin{array}{c}3 \text { to } 66 \mathrm{~mm} \\
7.7 \text { to } 25.6^{\circ} \mathrm{C}\end{array}$ & 2017 \\
\hline P7 & $\begin{array}{l}\text { Apis mellifera } \\
\text { sahariansis }\end{array}$ & ARFOUD & $31.4366^{\circ} \mathrm{N}$ & $4.2344^{\circ} \mathrm{W}$ & 807 & $\begin{array}{c}3 \text { to } 14 \mathrm{~mm} \\
10.2 \text { to } 33.3^{\circ} \mathrm{C}\end{array}$ & 2017 \\
\hline P8 & $\begin{array}{c}\text { Apis mellifera } \\
\text { intermissa }\end{array}$ & TAZA & $\begin{array}{c}34^{\circ} 12^{\prime} \\
36.00^{\prime \prime} \mathrm{N}\end{array}$ & $4^{\circ} 00^{\prime} 36.00^{\prime \prime} \mathrm{W}$ & 550 & $\begin{array}{l}2 \text { to } 91 \mathrm{~mm} \\
9.5 \text { to } 28.2^{\circ} \mathrm{C}\end{array}$ & 2017 \\
\hline
\end{tabular}

measured according to the method of Kumazawa et al. [17]. $50 \mu \mathrm{L}$ of the ethanolic extract of bee pollen was added to $825 \mu \mathrm{L}$ of ethanolic solution of DPPH. Absorbance measurements were read at $517 \mathrm{~nm}$, after $1 \mathrm{~h}$ of incubation. The $\mathrm{IC}_{50}$ was calculated based on the graph obtained by the percentage of inhibition, using the following formula:

$$
\% \text { inhibition }=[(A 0-A 1 \mid A 0) \times 100] .
$$

Tests were conducted in triplicate, and the results are given as mean \pm SD.

2.13. Reducing Power (RP). The reducing power was determined according to the method described by Moreira et al. [18]. Ethanolic extract of bee pollen $(50 \mu \mathrm{L})$ was mixed with $200 \mu \mathrm{L}$ of $0.2 \mathrm{M}$ sodium phosphate buffer ( $\mathrm{pH} 6.6$ ), and $200 \mu \mathrm{L}$ of $1 \%$ potassium ferricyanide. The mixture was incubated at $50^{\circ} \mathrm{C}$ for $20 \mathrm{~min}$, and $200 \mu \mathrm{L}$ of $10 \%$ trichloroacetic acid, $200 \mu \mathrm{L}$ of distilled water, and $120 \mu \mathrm{L}$ of $0.1 \%$ of ferric chloride was added. The absorbance was measured at $700 \mathrm{~nm}$. Extract concentration providing 0.5 of absorbance $\left(\mathrm{EC}_{50}\right)$ was calculated from the graph of absorbance against extract concentration in the solution. Ascorbic acid was used as a positive control. Tests were conducted in triplicate, and the results were given as mean \pm SD .

2.14. Scavenging Activity of ABTS Radical Cation. The ABTS radical cation $\left(\mathrm{ABTS}^{+}\right)$scavenging activity was measured according to the method described by Miguel et al. [19]. Briefly, the $\mathrm{ABTS}^{+}$radical was generated by the reaction of $(7 \mathrm{mM})$ ABTS aqueous solution with $\mathrm{K}_{2} \mathrm{~S}_{2} \mathrm{O}_{8}(2.45 \mathrm{mM})$ in the dark for $16 \mathrm{~h}$ and adjusting the Abs $734 \mathrm{~nm}$ to 0.7 at room temperature. Ethanolic extract of bee pollen $(50 \mu \mathrm{L})$ was added to $(825 \mu \mathrm{L}) \mathrm{ABTS}^{+}$solution, and the absorbance was measured at $734 \mathrm{~nm}, 5 \mathrm{~min}$ after the initial mixing, using water as the blank. The $\mathrm{IC}_{50}$ was calculated using the percentage of inhibition of ABTS by the following formula:

$$
\% \text { inhibition }=[(A 0-A 1 \mid A 0) \times 100] .
$$

Tests were conducted in triplicate, and the results are given as mean $\pm \mathrm{SD}$.

2.15. Statistical Analysis. Graphpad prism 5 was used for statistical analysis, comparisons of bee pollen samples were performed by ANOVA followed by Tukey's test, and the principal component analysis (PCA) was accomplished using Past 3.

\section{Results and Discussion}

3.1. Botanical Identification of Bee Pollen by Scanning Electron Microscopy. Scanning electron microscopy analysis of bee pollen samples, presented in Figure 1 and Table 2, showed that the botanical origin of each bee pollen sample according to its predominant pollen grains was as follows: the botanical origin of bee pollen sample from LARACHE was Coriandrum sativum (Apiaceae) (70\%), the botanical origin of bee pollen sample from KHENICHAT was Ulex europaeus (Fabaceae) (73\%), the botanical origin of bee pollen sample from HED KOURT was Scorzonera cana (Asteraceae) (77\%), the botanical origin of bee pollen sample from KENITRA was Trifolium pretense (Fabaceae) (76\%), the botanical origin of bee pollen sample from FEZ was Ulex europaeus (Fabaceae) (64\%), the botanical origin of bee pollen sample from SEFROU was Reseda luteola (Resedaceae) (60\%), the botanical origin of bee pollen sample from ARFOUD was Spiraea salicifolia (Rosaceae) (68\%), and the botanical origin of bee pollen sample from TAZA was Lamium galeobdolon (Lamiaceae) (59\%). The bee pollen identification was carried out by comparing the morphology, sizes, and exine ornamentations of bee pollen studied to that described elsewhere [20-26]. Louveaux et al. reported that when the percentage of pollen grains is $>45 \%$ of total, the sample is classified as monofloral [9]. Thus, all samples studied were classified as monofloral. Carpes et al. showed that the 


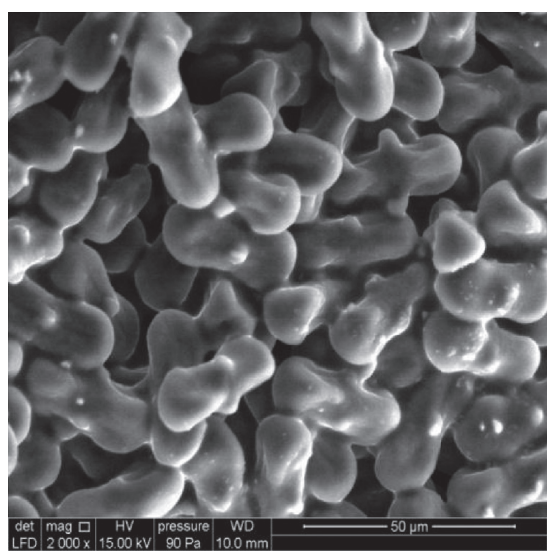

(a)

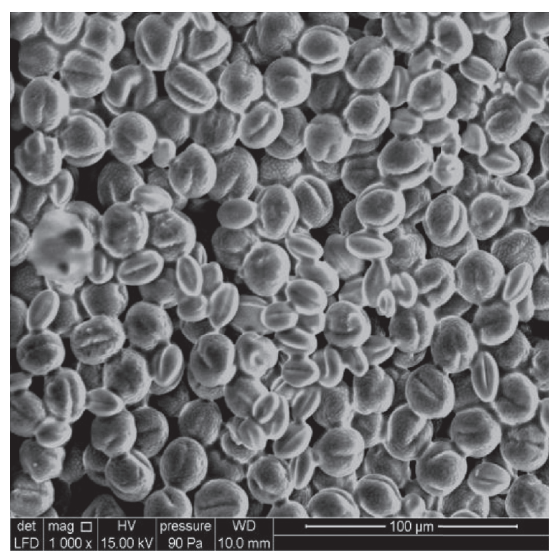

(d)

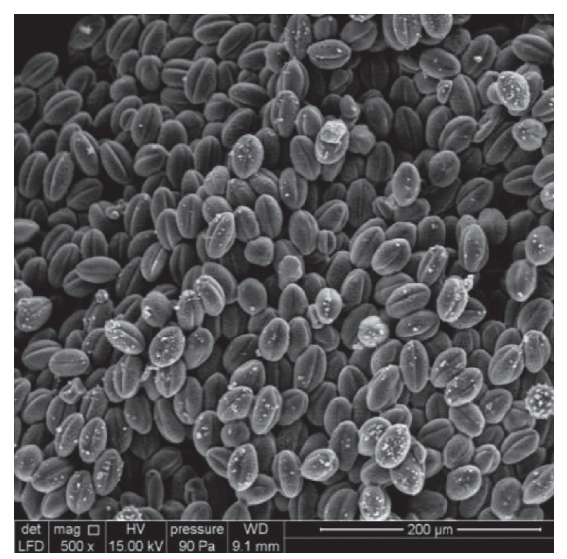

(b)

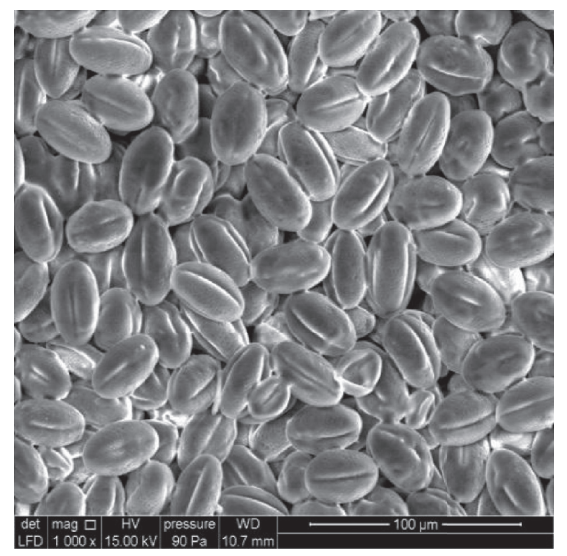

(e)

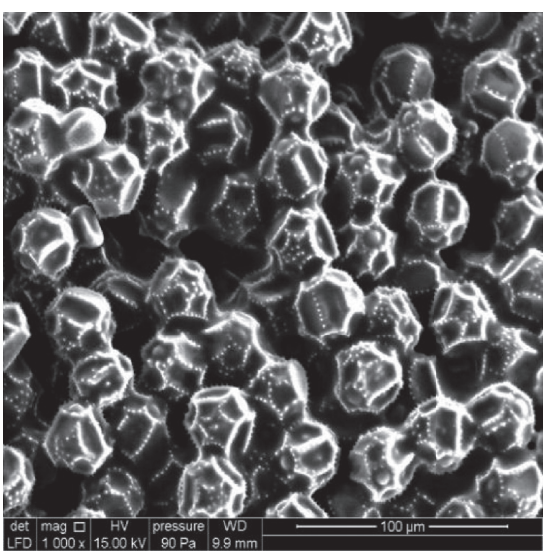

(c)

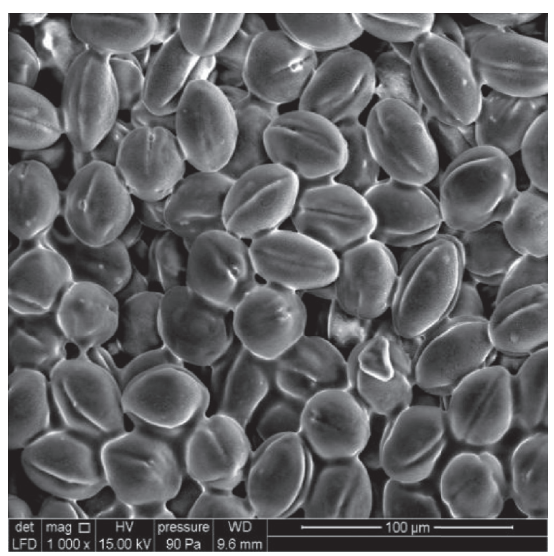

(f)

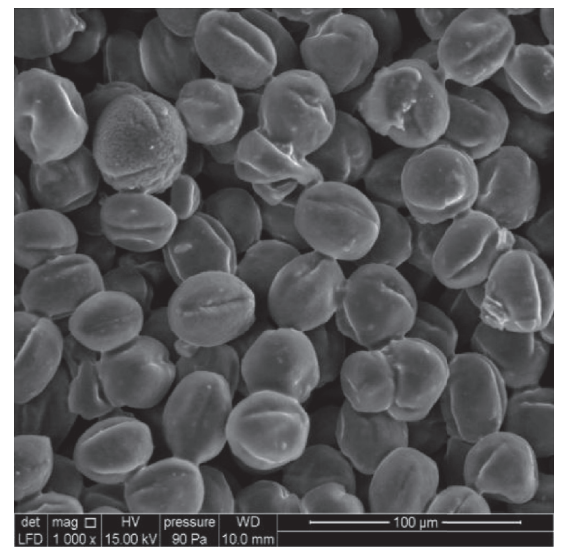

(g)

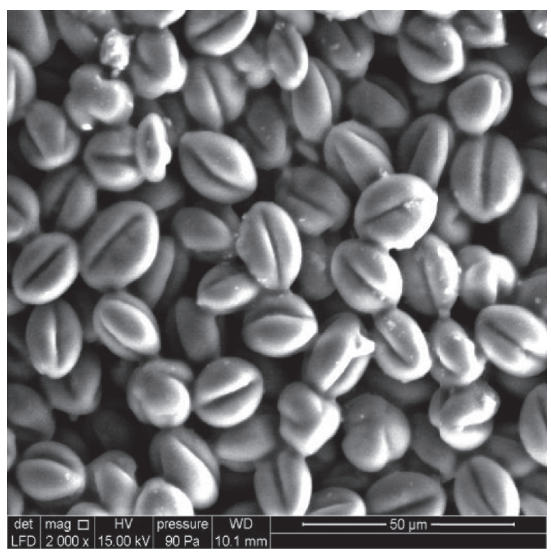

(h)

Figure 1: Scanning Electron Microscopy (SEM) micrographs of 193 bee pollen samples. (a) P1: Coriandrum sativum (Apiaceae). (b) P2: Ulex europaeus (Fabaceae). (c) P3: Scorzonera cana (Asteraceae). (d) P4: Trifolium pretense (Fabaceae). (e) P5: Ulex europaeus (Fabaceae). (f) P6: Reseda luteola (Resedaceae). (g) P7: Spiraea salicifolia (Rosaceae). (h) P8: Lamium galeobdolon (Lamiaceae).

nutritional quality of pollen grains makes bees attractive to a single floral source [27].

3.2. $p H$. The $\mathrm{pH}$ measurement is a simple and easy quality parameter to assess; a very low $\mathrm{pH}$ indicates bacterial deterioration of bee pollen because of its high moisture content [1]. Our results showed that there were no significant differences between all samples concerning $\mathrm{pH}$, and the values ranged from $4.19 \pm 0.17$ in $\mathrm{P} 4$ to $4.82 \pm 0.36$ in P2 (Table 3); this value was similar to the one found in the Colombian bee pollen which showed $\mathrm{pH}$ values ranged between 3.8 and 5.4 [12]. Our bee pollens respond to the Argentinean regulation which fixed a $\mathrm{pH}$ range from 4 to 6 [28].

3.3. Moisture. The results of moisture are shown in Table 3. Moisture presented values between $10.7 \%$ for sample P8 and 
TABLE 2: Palynological analysis of bee pollen samples.

\begin{tabular}{|c|c|c|c|c|}
\hline \multirow{2}{*}{ Samples } & \multirow{2}{*}{ 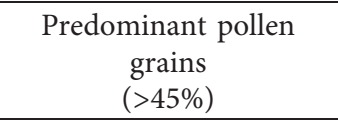 } & \multirow{2}{*}{$\begin{array}{c}\text { Secondary pollen } \\
\text { grains } \\
(16-45 \%) \\
\end{array}$} & \multicolumn{2}{|r|}{ Important minor pollenMinor pollen } \\
\hline & & & $(3-15 \%)$ & $(<3 \%)$ \\
\hline $\mathrm{P} 1$ & $\begin{array}{c}\text { Coriandrum sativum } \\
\text { (70\%) } \\
\text { (Apiaceae) }\end{array}$ & Cistaceae $(20 \%)$ & Asteraceae (7\%) & $\begin{array}{c}\text { Cactaceae; Salicaceae; Rutaceae; Rosaceae; Fabaceae; } \\
\text { Ericaceae }\end{array}$ \\
\hline $\mathrm{P} 2$ & $\begin{array}{c}\text { Ulex europaeus }(73 \%) \\
\text { (Fabaceae) }\end{array}$ & Lamiaceae (17\%) & Rosaceae $(8 \%)$ & Moraceae; Oleaceae; Asteraceae \\
\hline P3 & $\begin{array}{c}\text { Scorzonera cana }(77 \%) \\
\text { (Asteraceae) }\end{array}$ & Rhamnaceae (18\%) & $\begin{array}{l}\text { Boraginaceae } \\
\quad(4 \%)\end{array}$ & Lamiaceae; Poaceae \\
\hline $\mathrm{P} 4$ & $\begin{array}{c}\text { Trifolium pretense }(76 \%) \\
\text { (Fabaceae) }\end{array}$ & Lamiaceae (19\%) & Cistaceae (5\%) & Boraginaceae; Rosaceae \\
\hline P5 & $\begin{array}{l}\text { Ulex europaeus }(64 \%) \\
\text { (Fabaceae) }\end{array}$ & Capparaceae (20\%) & $\begin{array}{l}\text { Lamiaceae }(4 \%) \\
\text { Rosaceae }(10 \%)\end{array}$ & Ranunculaceae; Papaveraceae \\
\hline P6 & $\begin{array}{l}\text { Reseda luteola (60\%) } \\
\text { (Resedaceae) }\end{array}$ & Fagaceae $(29 \%)$ & Myrthaceae (9\%) & Malvaceae; Apiaceae \\
\hline P7 & $\begin{array}{c}\text { Spiraea salicifolia }(68 \%) \\
\text { (Rosaceae) }\end{array}$ & Apiaceae (19\%) & $\begin{array}{c}\text { Brassicaceae }(6 \%) \\
\text { Fabaceae }(5 \%)\end{array}$ & Asteraceae; Lamiaceae \\
\hline P8 & $\begin{array}{c}\text { Lamium galeobdolon } \\
\text { (59\%) } \\
\text { (Lamiaceae) }\end{array}$ & Ericaceae $(25 \%)$ & Asteraceae (14\%) & Rutaceae; Liliaceae; Ranunculaceae \\
\hline
\end{tabular}

TABLE 3: $\mathrm{pH}$, Ash, moisture, and protein analysis of monofloral bee pollen.

\begin{tabular}{lcccc}
\hline Samples & $\mathrm{pH}$ & Ash \% & Moisture \% & $\begin{array}{c}\text { Protein } \\
(\mathrm{g} / 100 \mathrm{~g})\end{array}$ \\
\hline P1 & $4.66 \pm 0.01^{\mathrm{a}}$ & $4.22 \pm 0.08^{\mathrm{a}}$ & $21.21 \pm 0.01^{\mathrm{d}}$ & $24.55 \pm 0.54^{\mathrm{c}}$ \\
P2 & $4.82 \pm 0.36^{\mathrm{a}}$ & $2.91 \pm 0.03^{\mathrm{d}}$ & $19.2 \pm 0.03^{\mathrm{f}}$ & $22.75 \pm 0.51^{\mathrm{e}}$ \\
P3 & $4.70 \pm 0.1^{\mathrm{a}}$ & $3.2 \pm 0.05^{\mathrm{c}}$ & $22.4 \pm 0.06^{\mathrm{c}}$ & $27.57 \pm 0.42^{\mathrm{b}}$ \\
P4 & $4.19 \pm 0.17^{\mathrm{a}}$ & $4.02 \pm 0.04^{\mathrm{b}}$ & $26.8 \pm 0.01^{\mathrm{a}}$ & $25.51 \pm 0.56^{\mathrm{c}}$ \\
P5 & $4.32 \pm 0.39^{\mathrm{a}}$ & $2.96 \pm 0.03^{\mathrm{d}}$ & $20.1 \pm 0.07^{\mathrm{e}}$ & $28.04 \pm 0.24^{\mathrm{b}}$ \\
P6 & $4.38 \pm 0.25^{\mathrm{a}}$ & $1.81 \pm 0.10^{\mathrm{f}}$ & $23.01 \pm 0.03^{\mathrm{b}}$ & $22.33 \pm 0.42^{\mathrm{e}}$ \\
P7 & $4.24 \pm 0.15^{\mathrm{a}}$ & $2.3 \pm 0.04^{\mathrm{e}}$ & $18.9 \pm 0.04 \mathrm{~g}$ & $19.86 \pm 0.36^{\mathrm{d}}$ \\
P8 & $4.72 \pm 0.12^{\mathrm{a}}$ & $2.95 \pm 0.07^{\mathrm{d}}$ & $10.7 \pm 0.04 \mathrm{~h}$ & $30.32 \pm 0.12^{\mathrm{a}}$ \\
\hline
\end{tabular}

Values in the same column followed by the same letter are not significantly different.

$26.8 \%$ for sample P4. Those values are comparable with the results presented in Romanian research [29]; our samples showed an average of moisture higher than that found by Radev and Bobis et al. [30,31]. According to Campos et al. and Bogdanov $[1,32]$, fresh bee pollen should contain between $20 \%$ and $30 \%$ of water; this condition allowed us to classify our samples as follows: P1, P3, P4, P5, and P6 are fresh bee pollen, while P2, P7, and P8 are initiated to dry out.

The fresh bee pollen has a biological and nutritional value more important than dried bee pollen, while the high content of water in fresh bee pollen makes it an ideal culture medium for microorganisms, and to preserve the good quality of bee pollen, it should be harvested daily and stored under nitrogen until consumption [33]. On the other hand, for dry bee pollen, the percentage of humidity must be less than $6 \%$, to be stored for 15 months. [32].

3.4. Ash Content. For the analyzed samples, ash amount showed a significant difference and ranged from $1.81 \pm 0.10 \%$ in P6 to $4.02 \pm 0.04 \%$ in P1 (Table 3). Our results were similar to the results shown in those of South African bee pollen [34]. These results fulfill with the Brazilian and Argentinean regulatory specifications which fixed a maximum of $4 \%[35,36]$ and the Switzerland regulation reporting a range of 2 and $6 \%$ for this parameter. [37] The ash content is a quality parameter that can be impacted by the soil type, the botanical origin, and the plant's ability to accumulate minerals $[3,38]$.

3.5. Protein Content. Bee pollen provides the required nutrients for the development of the bee's organs. It is the only naturally available source of protein, which is the main source of honey bees' nutrition. In this study, the total protein content of the analyzed samples was summarized in Table 3. Results showed values varied between $19.86 \pm 0.36 \mathrm{~g} /$ $100 \mathrm{~g}$ in P7 and $30.32 \pm 0.12 \mathrm{~g} / 100 \mathrm{~g}$ in P8. Our results agree with the standards described by Campos et al. and by Bogdanov which fixed the content of protein in 10 to $40 \mathrm{~g} /$ $100 \mathrm{~g}$ of bee pollen dry weight $[1,32,37]$.

3.6. Mineral Content. Regarding mineral composition, eleven elements were investigated, and the results are represented in Table 4. Potassium was the most abundant element in all samples with an average amount that ranged from $485.37 \pm 9.30 \mathrm{mg} / \mathrm{kg}$ in P3 to $4594.25 \pm 18.26 \mathrm{mg} / \mathrm{kg}$ in $\mathrm{P} 5$, followed by magnesium with an amount that ranged from $68.73 \pm 5.30 \mathrm{in} \mathrm{P3} \mathrm{mg/kg} \mathrm{to} 793.35 \pm 13.64 \mathrm{mg} / \mathrm{kg}$ in P5, sodium with an amount that ranged from $91.85 \pm .61 \mathrm{mg} / \mathrm{kg}$ in P8 to $397.22 \pm 4.12 \mathrm{mg} / \mathrm{kg}$ in P1, iron with an amount that ranged from $17.07 \pm 2.80 \mathrm{mg} / \mathrm{kg}$ to $68.86 \pm 4.24 \mathrm{mg} / \mathrm{kg}$ in $\mathrm{P} 1$, aluminum with an amount that ranged from $16.43 \pm 2.39 \mathrm{mg} / \mathrm{kg}$ in $\mathrm{P} 6$ to $126.3 \pm 7.33 \mathrm{mg} / \mathrm{kg}$ in $\mathrm{P} 1$, zinc with an amount that ranged from $15.28 \pm 0.94 \mathrm{mg} / \mathrm{kg}$ in P3 to $38.83 \pm 4.36 \mathrm{mg} / \mathrm{kg}$ in $\mathrm{P} 6$, calcium with an amount that ranged from $2.24 \pm 1.03 \mathrm{mg} / \mathrm{kg}$ in P3 to $22.73 \pm 2.57 \mathrm{mg} / \mathrm{kg}$ in 


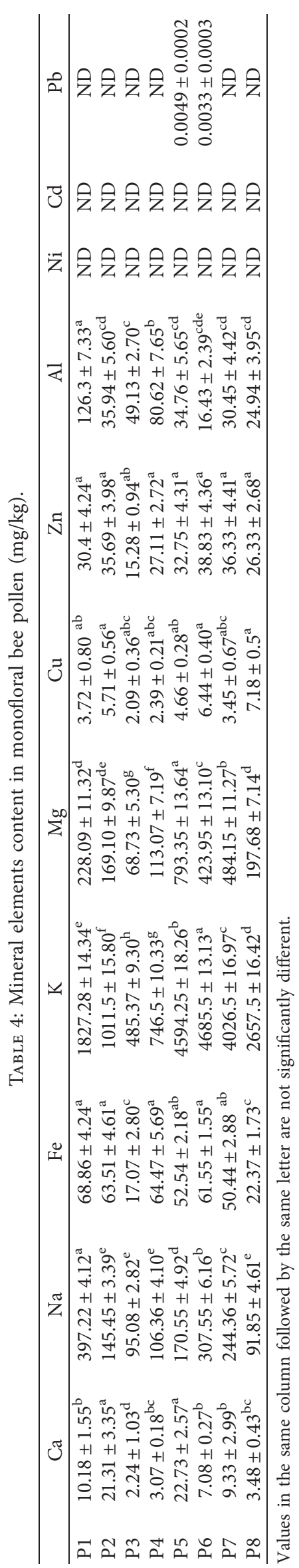


P5, and finally, copper with an amount that ranged from $2.09 \pm 0.36 \mathrm{mg} / \mathrm{kg}$ to $7.18 \pm 0.5 \mathrm{mg} / \mathrm{kg}$ in $\mathrm{P} 8$. These results follow the same order as the results found in Turkish, Colombian, and Argentinean studies [12, 28, 39]. The content in minerals depends on the botanical and geographical origin [6]. Concerning heavy metals, all samples are free except two (P5, P6) where we found $0.0049 \pm 0.0002 \mathrm{mg} / \mathrm{kg}$ and $0.0033 \pm 0.0003 \mathrm{mg} / \mathrm{kg}$ of lead, respectively; these values remain within the acceptable limits of bee pollen quality requiring that the lead content must not exceed $50 \mu \mathrm{g} / 100 \mathrm{~g}$ [1].

\subsection{Phenolic and Flavones/Flavonols Contents.} Polyphenols or phenolic compounds are plant secondary metabolites present in all parts of plants (roots, stems, leaves, flowers, pollen, fruits, seeds, and wood), while dietary phenols are involved in the potential health benefits for humans [40]. More than 8000 polyphenols are identified in plants; the most representative classes are flavonoids, phenolic acids, stilbenes, and lignans; these phytocompounds present a wide range of biological activities, and provide large protection against many chronic pathologies involving oxidative stress such as cancer, diabetes, cardiovascular affections, and aging [41]. The main common group of polyphenols in the human diet are flavonoids which are known for their antioxidant activities through scavenging or chelating mechanism [42]. Bee pollen exhibits a wide range of phenolic compounds such as quercetin, vanillic acids, protocatechuic acids, and many other phenolic compounds [43]. Its phenolic content varies according to its botanical and geographic origins, as well as soil type, climatic conditions, and beekeeper activities [44]. Total phenolic and flavones/flavonols amount of the eight analyzed bee pollen samples is presented in Table 5 which showed a significant variation between all samples. The total phenolic content varied between $8.070 \pm 1.037 \mathrm{mgGAE} / \mathrm{g}$ in $\mathrm{P} 7$ and $32.387 \pm 0.148 \mathrm{mgGAE} / \mathrm{g}$ in P6; these results were significantly higher than those found in the Romanian, Spanish, and Portuguese collected bee pollen with a mean value of $12.69 \pm 0.21 \mathrm{mgGAE} / \mathrm{g}, \quad 12.24 \pm 2.0 \mathrm{mgGAE} / \mathrm{g}, \quad$ and $16.4 \pm 2.0 \mathrm{mgGAE} / \mathrm{g}$, respectively $[11,45,46]$. The flavones/ flavonols content ranged between $0.202 \pm 0.044 \mathrm{mgQE} / \mathrm{g}$ in $\mathrm{P} 6$ and $6.30 \pm 0.37 \mathrm{mgQE} / \mathrm{g}$ in P3; our results are higher than those obtained by Tavdidishvili et al. [47].

3.8. Total Antioxidant Capacity and Antioxidant Activities (DPPH, RP, and ABTS). The total antioxidant capacity was evaluated by the phosphomolebdeneum test, while the antioxidant activity was assessed by three methods: DPPH, ABTS, and RP assays (Table 5), and the results of DPPH showed $\mathrm{IC}_{50}$ values ranged between $0.245 \pm 0.009 \mathrm{mg} / \mathrm{ml}$ in $\mathrm{P} 2$ and $0.832 \pm 0.069 \mathrm{mg} / \mathrm{ml}$ in P7, which were lower than those obtained in a Spanish study (mean value $=3.0 \pm 0.7 \mathrm{mg} / \mathrm{mL}$ ) [11]. Antioxidant activity determined by the reducing power (RP) method showed the maximum inhibition in $\mathrm{P} 1\left(\mathrm{EC}_{50}=0.133 \pm 0.036 \mathrm{mg} / \mathrm{ml}\right)$ and the lowest inhibition in $\mathrm{P} 6\left(\mathrm{EC}_{50}=0.790 \pm 0.175 \mathrm{mg} / \mathrm{ml}\right)$; these values were much higher than that of ascorbic acid used as standard $(0.031 \pm 0.070 \mathrm{mg} / \mathrm{ml})$. Results of ABTS assay showed a variation of $\mathrm{IC}_{50}$ from $0.190 \pm 0.005 \mathrm{mg} / \mathrm{ml}$ to $0.896 \pm 0.051 \mathrm{mg} / \mathrm{ml}$. Concerning the total antioxidant capacity (TAC), all samples showed a significant difference, and values ranged between $3.98 \pm 0.16 \mathrm{mgEAA} / \mathrm{g}$ in $\mathrm{P} 1$ and $9.69 \pm 0.34 \mathrm{mgEAA} / \mathrm{g}$ in P3. The results of the antioxidant activities of our samples seem to be stronger than Brazilian bee pollen [48].

3.9. ACP Analysis. The principal component analysis is mentioned in Figure 2. The results of the homogeneity of bee pollen samples based on palynological analysis, mineral, moisture, and ash content are represented in Figure 2(a): the first component explained (30.81\%) and represented in its positive part: $\mathrm{Fe}, \mathrm{Na}, \mathrm{Ca}, \mathrm{Zn}, \mathrm{Mg}, \mathrm{K}$, and $\mathrm{Cu}$ and the results of palynological analyzes of Ulex europaeus, Spiraea salicifolia, Lamium galeobdolon, and Reseda luteola pollen grains, while ash, moisture, $\mathrm{Al}$, and Coriandrum sativum, Trifolium pretense, and Scorzonera cana pollen grains percentages were in the negative part. The second principal component explained (22.884\%) of the given results and represented in the positive parts: ash, $\mathrm{Al}$, moisture, $\mathrm{Fe}, \mathrm{Na}, \mathrm{Zn}, \mathrm{Ca}, \mathrm{Mg}$, and $\mathrm{K}$ and palynological analyzes results representing Trifolium pretense, Coriandrum sativum, Ulex europaeus, Spiraea salicifolia, and Reseda luteola pollen grains, whereas in the negative parts, we found $\mathrm{Cu}$ and Lamium galeobdolon and Scorzonera cana pollen grains percentages. The results represented in Figure 2(a) showed that $\mathrm{K}, \mathrm{Mg}, \mathrm{Cu}$, and $\mathrm{Zn}$ correlated negatively with ash. The minerals $\mathrm{Ca}, \mathrm{Zn}, \mathrm{Mg}, \mathrm{K}$, and $\mathrm{Cu}$ correlated with each other positively, while $\mathrm{Al}$ correlated with all minerals studied negatively except $\mathrm{Fe}$ and $\mathrm{Na}$. The monofloral bee pollen samples P2 (70\% of Ulex europaeus pollen grains), P5 (64\% of Ulex europaeus pollen grains), P6 (60\% of Reseda luteola pollen grains), and P7 (68\% of Spiraea salicifolia pollen grains) shared the features regarding $\mathrm{Ca}, \mathrm{Zn}, \mathrm{Mg}, \mathrm{K}$, and $\mathrm{Cu}$, while the content of predominant pollen grains ( $70 \%$ of Coriandrum sativum) in bee pollen sample P1 correlated positively with $\mathrm{Fe}, \mathrm{Na}$, and $\mathrm{Al}$, which suggests that, in addition to the soil type, the minerals content in bee pollen was affected by the botanical origin. Our findings go in hand with those found by Stanciu et al. and Kostić et al. [49, 50].

The results of the homogeneity of bee pollen samples based on total phenolic, flavones/flavonols, and antioxidant activities (TAC, DPPH, and RP) are represented in Figure 2(b); the first component explained (42.785\%), represented in its positive parts reducing power (RP), total phenolic, flavones/flavonols, and total antioxidant capacity, while in the negative parts, we found DPPH and ABTS. The second component explained (21.866\%), represented in its positive parts DPPH, RP, and total phenolic, while in the negative parts, it represents flavones/flavonols, total antioxidant capacity, and ABTS. The results of the PCA indicate that DPPH and ABTS correlated negatively with total antioxidant capacity, flavones/flavonols, and total phenolic, while antioxidant capacity, flavones/flavonols, and total phenolic correlated with each other positively. The variability of minerals and antioxidant contents could be 
TABLE 5: The antioxidant content and activities of the ethanolic extract of monofloral bee pollens.

\begin{tabular}{|c|c|c|c|c|c|c|}
\hline Sample & $\begin{array}{c}\mathrm{DPPH} \\
\mathrm{IC}_{50}(\mathrm{mg} / \mathrm{ml})\end{array}$ & $\begin{array}{c}\mathrm{RP} \\
\mathrm{EC}_{50}(\mathrm{mg} / \mathrm{ml})\end{array}$ & $\begin{array}{c}\text { ABTS } \\
\mathrm{IC}_{50}(\mathrm{mg} / \mathrm{ml})\end{array}$ & $\begin{array}{c}\text { TAC } \\
(\mathrm{mg} \text { EAA/g) }\end{array}$ & $\begin{array}{c}\text { Flavones and flavonols } \\
(\mathrm{mg} \mathrm{EQ} / \mathrm{g})\end{array}$ & $\begin{array}{l}\text { Total phenolic } \\
\text { (mg GAE/g) }\end{array}$ \\
\hline P1 & $0.78 \pm 0.012^{\mathrm{d}}$ & $0.133 \pm 0.036^{\mathrm{a}}$ & $0.896 \pm 0.051^{\mathrm{f}}$ & $3.984 \pm 0.163^{c}$ & $2.233 \pm 0.275^{\mathrm{c}}$ & $13.730 \pm 2.816^{\mathrm{abc}}$ \\
\hline $\mathrm{P} 2$ & $0.245 \pm 0.009^{\mathrm{b}}$ & $0.380 \pm 0.089^{\mathrm{abc}}$ & $0.190 \pm 0.005^{\mathrm{b}}$ & $4.650 \pm 0.532^{c}$ & $1.626 \pm 0.055^{c}$ & $22.954 \pm 3.112^{\mathrm{ab}}$ \\
\hline P3 & $0.283 \pm 0.004^{\mathrm{b}}$ & $0.431 \pm 0.026^{\mathrm{abc}}$ & $0.204 \pm 0.006^{\mathrm{b}}$ & $9.693 \pm 0.343^{\mathrm{a}}$ & $6.303 \pm 0.374^{\mathrm{a}}$ & $27.985 \pm 3.042^{\mathrm{a}}$ \\
\hline $\mathrm{P} 4$ & $0.450 \pm 0.060^{c}$ & $0.204 \pm 0.127^{\mathrm{ab}}$ & $0.237 \pm 0.047^{\mathrm{b}}$ & $6.103 \pm 0.163^{b}$ & $4.871 \pm 0.110^{\mathrm{b}}$ & $22.744 \pm 1.334^{\mathrm{ab}}$ \\
\hline P5 & $0.663 \pm 0.086^{\mathrm{d}}$ & $0.731 \pm 0.085^{\mathrm{d}}$ & $0.314 \pm 0.009^{b c}$ & $5.472 \pm 0.335^{\mathrm{b}}$ & $1.011 \pm 0.132^{\mathrm{cd}}$ & $18.342 \pm 2.816^{\mathrm{ab}}$ \\
\hline P6 & $0.795 \pm 0.016^{\mathrm{d}}$ & $0.790 \pm 0.175^{\mathrm{d}}$ & $0.414 \pm 0.023^{\mathrm{d}}$ & $4.140 \pm 0.057^{\mathrm{c}}$ & $0.202 \pm 0.044^{\mathrm{f}}$ & $32.387 \pm 0.148^{\mathrm{a}}$ \\
\hline P7 & $0.832 \pm 0.069^{\mathrm{df}}$ & $0.458 \pm 0.198^{\mathrm{abc}}$ & $0.576 \pm 0.045^{\mathrm{e}}$ & $6.827 \pm 0.024^{\mathrm{b}}$ & $1.875 \pm 0.363^{c}$ & $8.070 \pm 1.037^{\mathrm{abc}}$ \\
\hline P8 & $0.753 \pm 0.075^{\mathrm{d}}$ & $0.238 \pm 0.091^{\mathrm{ab}}$ & $0.597 \pm 0.035^{\mathrm{e}}$ & $9.027 \pm 0.090^{\mathrm{a}}$ & $0.918 \pm 0.044^{\text {cde }}$ & $28.824 \pm 0.148^{\mathrm{a}}$ \\
\hline BHT & $0.021 \pm 0.01^{\mathrm{a}}$ & - & - & - & - & - \\
\hline Gallic acid & - & - & $0.019 \pm 0.001^{\mathrm{a}}$ & - & - & - \\
\hline Ascorbic acid & - & $0.031 \pm 0.070^{\mathrm{a}}$ & - & - & - & - \\
\hline
\end{tabular}

Values in the same column followed by the same letter are not significantly different.

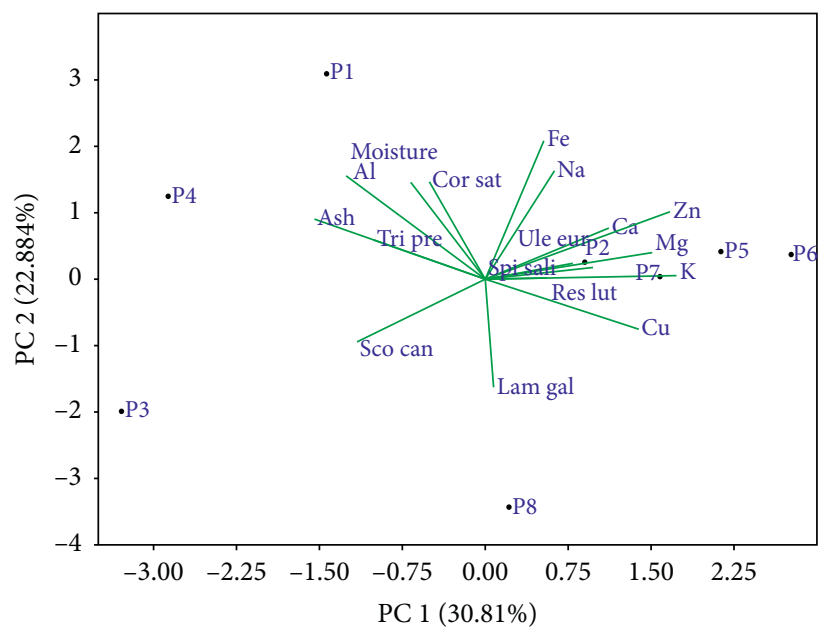

(a)

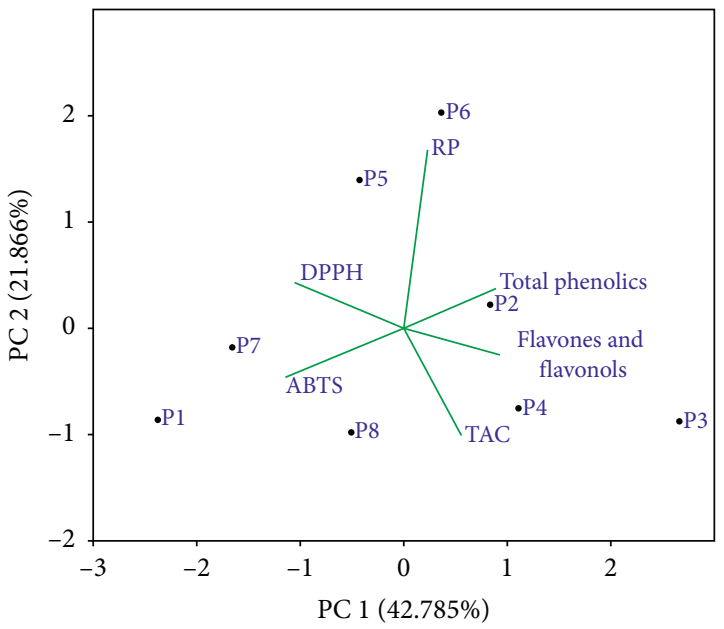

(b)

Figure 2: Principal component analysis: (a) biplots of monofloral bee pollen samples using palynological analysis (cor sat: Coriandrum sativum; ule eur: Ulex europaeus; sco can: Scorzonera cana; tri pre: Trifolium pretense; res lut: Reseda luteola; spi sal: Spiraea salicifolia; and lam gal: Lamium galeobdolon), mineral content, ash, and moisture; (b) biplots of monofloral bee pollen using total phenolic, flavones/ flavonols, total antioxidant activity, and the antioxidant activities(ABTS, RP, and DPPH).

attributed to the geographical location and botanical origin. [51].

The results also indicate variability in physicochemical analysis and antioxidant activity in P5 and P2, even if they have the same botanical origin (Ulex europaeus). The most likely explanation of these findings is the presence of secondary pollen (Table 2) that contribute to the antioxidant activity, and mineral content of the studied samples [52]. In addition, bee pollen sample P2 was from KHENICHAT, while bee pollen sample P5 was from FEZ (Table 1); therefore, they were produced in different geographic and climatic areas, which contributes to the variability of these two samples in the studied parameters [51].

\section{Conclusions}

In this work, palynological, physicochemical characterization, protein content, and antioxidant activities were assessed for the first time in Moroccan bee pollen. The results of the current study showed that all samples responded to the quality criteria and exhibited a strong antioxidant potential in vitro. This research is the first step towards the certification and the standardization of bee pollen produced in Morocco.

\section{Data Availability}

The data used to support the findings of this study are available from the corresponding author upon request.

\section{Conflicts of Interest}

The authors declare that they have no conflicts of interest.

\section{Acknowledgments}

This work was supported by a grant from the University Sidi Mohamed Ben Abdallah for Laboratory PhysiologyPharmacology \& Environmental Health (USMBA/ L08FSDM). 


\section{References}

[1] M. G. R. Campos, S. Bogdanov, L. B. de Almeida-Muradian et al., "Pollen composition and standardisation of analytical methods," Journal of Apicultural Research, vol. 47, no. 2, pp. 154-161, 2008 Jan.

[2] J. A. G. Sattler, A. A. M. De-Melo, K. S. d. Nascimento et al., "Essential minerals and inorganic contaminants (barium, cadmium, lithium, lead and vanadium) in dried bee pollen produced in Rio Grande do Sul State, Brazil," Food Science and Technology, vol. 36, no. 3, pp. 505-509, 2016.

[3] M. T. O. Villanueva, A. D. Marquina, R. B. Serrano, and G. B. Abellán, "The importance of bee-collected pollen in the diet: a study of its composition," International Journal of Food Sciences and Nutrition, vol. 53, no. 3, pp. 217-224, 2002.

[4] M. Kieliszek, K. Piwowarek, A. M. Kot, S. Błażejak, A. Chlebowska-Śmigiel, and I. Wolska, "Pollen and bee bread as new health-oriented products: a review," Trends in Food Science \& Technology, vol. 71, pp. 170-180, 2018.

[5] J. Kocot, M. Kiełczykowska, D. Luchowska-Kocot, J. Kurzepa, and I. Musik, "Antioxidant potential of propolis, bee pollen, and royal jelly: possible medical application," Oxidative Medicine and Cellular Longevity, vol. 2018, Article ID 7074209, , 2018.

[6] K. Komosinska-Vassev, P. Olczyk, J. Kaźmierczak, L. Mencner, and K. Olczyk, "Bee pollen: chemical composition and therapeutic application," Evidence-Based Complementary and Alternative Medicine, vol. 2015, Article ID 297425, 6 pages, 2015.

[7] A. Moujanni, A. K. Essamadi, and A. Terrab, "Beekeeping in Morocco: focus on honey production," International Journal of Innovation and Applied Studies, vol. 20, no. 1, pp. 52-78, 2017.

[8] J. de F. Almeida, D. Pereira, M Bianchin et al., "Lyophilized bee pollen extract: a natural antioxidant source to prevent lipid oxidation in refrigerated sausages," Journal of Food Science and Technology, vol. 76, pp. 299-305, 2017.

[9] J. Louveaux, A. Maurizio, and G. Vorwohl, "Methods of melissopalynology," Bee World, vol. 59, no. 4, pp. 139-157, 1978.

[10] M. Bakour, M. d. G. Campos, H. Imtara, and B. Lyoussi, "Antioxidant content and identification of phenolic/flavonoid compounds in the pollen of fourteen plants using HPLCDAD," Journal of Apicultural Research, vol. 59, no. 1, pp. 35-41, 2020.

[11] X. Feás, M. P. Vázquez-Tato, L. Estevinho, J. A. Seijas, and A. Iglesias, "Organic bee pollen: botanical origin, nutritional value, bioactive compounds, antioxidant activity and microbiological quality," Molecules, vol. 17, no. 7, pp. 8359-8377, 2012.

[12] C. Fuenmayor B, C. Zuluaga D, C. Díaz M, M. Quicazán de C, M. Cosio, and S. Mannino, "Evaluation of the physicochemical and functional properties of Colombian bee pollen," Revista MVZ Córdoba, vol. 19, no. 1, pp. 4003-4014, 2014.

[13] O. H. Lowry, N. J. Rosebrough, A. L. Farr, and R. J. Randall, "Protein measurement with the folin phenol reagent," The Journal of Biological Chemistry, vol. 193, no. 1, pp. 265-275, 1951.

[14] V. L. Singleton and J. A. Rossi, "Colorimetry of total phenolics with phosphomolybdic-phosphotungstic acid reagents," American Journal of Enology and Viticulture, vol. 16, no. 3, pp. 144-158, 1965.

[15] M. G. Miguel, S. Nunes, S. A. Dandlen, A. M. Cavaco, and M. D. Antunes, "Phenols and antioxidant activity of hydro- alcoholic extracts of propolis from algarve, south of portugal," Food and Chemical Toxicology, vol. 48, no. 12, pp. 3418-3423, 2010.

[16] P. Prieto, M. Pineda, and M. Aguilar, "Spectrophotometric quantitation of antioxidant capacity through the formation of a phosphomolybdenum complex: specific application to the determination of vitamin E," Analytical Biochemistry, vol. 269, no. 2, pp. 337-341, 1999.

[17] S. Kumazawa, T. Hamasaka, and T. Nakayama, "Antioxidant activity of propolis of various geographic origins," Food Chemistry, vol. 84, no. 3, pp. 329-339, 2004.

[18] L. Moreira, L. G. Dias, J. A. Pereira, and L. Estevinho, "Antioxidant properties, total phenols and pollen analysis of propolis samples from Portugal," Food and Chemical Toxicology, vol. 46, no. 11, pp. 3482-3485, 2008.

[19] M. d. G. Miguel, O. Doughmi, S. Aazza, D. Antunes, and B. Lyoussi, "Antioxidant, anti-inflammatory and acetylcholinesterase inhibitory activities of propolis from different regions of Morocco," Food Science and Biotechnology, vol. 23, no. 1, pp. 313-322, 2014.

[20] S. M. Naggar, "Taxonomic significance of pollen morphology in some taxa of resedaceae," Feddes Repertorium, vol. 113, pp. 518-527, 2002.

[21] V. D’Ávila, E. Menezes, V. Gonçalves-Esteves, C. Mendonça, R. Pereira, and T. Santos, "Morphological characterization of pollens from three apiaceae species and their ingestion by twelve-spotted lady beetle (coleoptera: coccinellidae)," Brazilian Journal of Biology, vol. 19, p. 76, 2016.

[22] Z. Atalay, F. Celep, B. Bilgili, and M. Doğan, "Pollen morphology of the genus lamium L. (Lamiaceae) and its systematic implications," Flora, vol. 219, pp. 68-84, 2016.

[23] P. Cubas and C. Pardo, "Pollen wall stratification trends inUlex (genisteae, papilionoideae: leguminosae) in the iberian peninsula," Grana, vol. 31, no. 3, pp. 177-185, 1992.

[24] T. A. Polyakova and G. N. Gataulina, "Morphology and variability of pollen of the genus spiraea L. (rosaceae) in siberia and the far east," Contemporary Problems of Ecology, vol. 1, no. 4, pp. 420-424, 2008.

[25] E. Hamzaoğlu, A. Aksoy, E. Martin, M. Pinar, and H. Colgecen, "A new record for the flora of turkey: scorzonera ketzkhovelii grossh,” Asteraceae, vol. 34, pp. 57-61, 2010.

[26] M. Koçyiğit and D. Mahmut, "Pollen morphology of some trifolium species which are favorite plants of honey bees in istanbul," İstanbul Journal of Pharmacy, vol. 43, no. 2, pp. 85-94, 2013.

[27] S. T. Carpes, I. S. R. Cabral, C. F. P. Luz, J. P. Capeletti, and S. M. Alencar, "Palynological and physicochemical characterization of apis mellifera L. bee pollen in the southern region of Brazil," Journal of Food Agriculture and Environment, vol. 73 pages, 2009.

[28] B. B. Coronel, D. Grasso, S. C. Pereira, and G. Fernández, "Caracterización bromatológica del polen apícola," Argentino, vol. 38, pp. 145-181, 2004.

[29] S. Roxana, D. Muhsin, B. Narcisa, and P. Ovidiu, "Physicochemical characteristics of fresh bee pollen from different botanical origins," Romanian Biotechnological Letters, vol. 23, pp. 13357-13365, 2018.

[30] Z. Radev, "Water content of honey bee collected pollen from 50 plants from bulgaria," Modern Concepts \& Developments in Agronomy, vol. 3, no. 3, pp. 314-316, 2018.

[31] O. Bobis, L. A. Marghitas, D. Dezmirean, O. Morar, V. Bonta, and F. Chirila, "Quality parameters and nutritional value of different commercial bee products," Bulletin of the University 
of Agricultural Sciences and Veterinary Medicine Cluj-Napoca Animal Science and Biotechnologies, vol. 67, no. 1-2, 2010.

[32] S. Bogdanov, "Quality and standards of pollen and beeswax," Apiacta, vol. 38, pp. 334-341, 2004.

[33] M. G. R. Campos, C. Frigerio, J. Lopes, and S. Bogdanov, "What is the future of bee-pollen?" Journal of ApiProduct and ApiMedical Science, vol. 2, no. 4, pp. 131-144, 2010.

[34] H. Human and S. W. Nicolson, "Nutritional content of fresh, bee-collected and stored pollen of aloe greatheadii var. davyana (asphodelaceae)," Phytochemistry, vol. 67, no. 14, pp. 1486-1492, 2006.

[35] L. B. Almeida-Muradian, L. C. Pamplona, S. Coimbra, and O. M. Barth, "Chemical composition and botanical evaluation of dried bee pollen pellets," Journal of Food Composition and Analysis, vol. 18, no. 1, pp. 105-111, 2005 Feb.

[36] Brasil, "Regulamentos técnicos de identidade e qualidade, de apitoxina, de cera de abelha, de geleia real," de Geleia Real Liofilizada, de Polen Apicola, de Propolis, de Extrato de Propolis) from the World Wide. Instrucao Normativa n. 3 de 2001 http://www.agricultura.gov.br/sda/dipoa, 2001.

[37] S. Bogdanov, Pollen: Collection, Harvest, Compostion, Quality in: Pollen Book, Stefan Bogdanov, Muehlethurnen, Switzerland, 2016.

[38] S. T. Carpes, G. B. Mourão, S. M. de Alencar, and M. L. Masson, "Chemical composition and free radical scavenging activity of Apis mellifera bee pollen from southern Brazil," Brazilian Journal of Food Technology, vol. 12, no. 1/4, pp. 220-229, 2009.

[39] Z. Kalaycioğlu, H. Kaygusuz, S. Döker, S. Kolaylı, and F. B. Erim, "Characterization of Turkish honeybee pollens by principal component analysis based on their individual organic acids, sugars, minerals, and antioxidant activities," LWT-Lebensmittel-Wissenschaft \& Technologie, vol. 84, pp. 402-408, 2017.

[40] K. Ganesan and B. Xu, "A critical review on polyphenols and health benefits of black soybeans," Nutrients, vol. 9, no. 5, 455 pages, 2017.

[41] K. B. Pandey and S. I. Rizvi, "Plant polyphenols as dietary antioxidants in human health and disease," Oxidative Medicine and Cellular Longevity, vol. 2, no. 5, pp. 270-278, 2009.

[42] N. Cook and S. Samman, "Flavonoids?Chemistry, metabolism, cardioprotective effects, and dietary sources," Journal of the European Ceramic Society, vol. 7, no. 2, pp. 66-76, 1996.

[43] A. M. Ares, S. Valverde, J. L. Bernal, M. J. Nozal, and J. Bernal, "Extraction and determination of bioactive compounds from bee pollen," Journal of Pharmaceutical and Biomedical Analysis, vol. 147, pp. 110-124, 2018.

[44] L. Sun, Y. Guo, Y. Zhang, and Y. Zhuang, "Antioxidant and anti-tyrosinase activities of phenolic extracts from rape bee pollen and inhibitory melanogenesis by cAMP/MITF/TYR pathway in B16 mouse melanoma cells," Frontiers in Pharmacology, vol. 8, p. 104, 2017.

[45] L. A. Mărghitaş, O. G. Stanciu, D. S. Dezmirean et al., "In vitro antioxidant capacity of honeybee-collected pollen of selected floral origin harvested from Romania," Food Chemistry, vol. 115, no. 3, pp. 878-883, 2009.

[46] J. Serra Bonvehí, M. Soliva Torrentó, and E. Centelles Lorente, "Evaluation of polyphenolic and flavonoid compounds in honeybee-collected pollen produced in Spain," Journal of Agricultural and Food Chemistry, vol. 49, no. 4, pp. 1848-1853, 2001.

[47] D. Tavdidishvili, T. Khutsidze, M. Pkhakadze, M. Vanidze, and A. Kalandia, "Flavonoids in Georgian bee bread and bee pollen," Journal of Chemistry and Chemical Engineering, vol. 8, pp. 676-681, 2014.

[48] K. R. L. Freire, A. C. S. Lins, M. C. Dórea, F. A. R. Santos, C. A. Camara, and T. M. S. Silva, "Palynological origin, phenolic content, and antioxidant properties of honeybeecollected pollen from bahia, Brazil," Molecules, vol. 17, no. 2, pp. 1652-1664, 2012.

[49] O. G. Stanciu, L. A. Marghitas, and D. Dezmirean, "Macroand oligo-mineral elements from honeybee-collected pollen and beebread harvested from Transylvania (Romania)," Bulletin UASVM Animal Science and Biotechnology, vol. 662 pages, 2009.

[50] A. Ž Kostić, M. B. Pešić, M. D. Mosić, B. P. Dojčinović, M. M. Natić, and T. JĐ, "Mineral content of bee pollen from Serbia/Sadržaj minerala u uzorcima pčelinjega peluda iz Srbije," Archives of Industrial Hygiene and Toxicology, vol. 66, no. 4, pp. 251-258, 2015.

[51] D. Aličić, Š. Drago, M. Jašić, H. Pašalić, and Đ. Ačkar, "Antioxidant properties of pollen," Hrana U Zdr Boles ZnanStručni Časopis Za Nutr Dijetetiku.vol. 3, no. 1, pp. 6-12, 2014.

[52] H. Laaroussi, T. Bouddine, M. Bakour, D. Ousaaid, and B. Lyoussi, "Physicochemical properties, mineral content, antioxidant activities, and microbiological quality of bupleurum spinosum gouan honey from the middle atlas in Morocco," Journal of Food Quality, vol. 2020, Article ID 7609454, 1 page, 2020. 